\title{
An Archaeological Survey of a Pipeline Right-of-way along Loop 1604 from IH-37 to the San Antonio River, Southeast Bexar County, Texas
}

\author{
David L. Nickels \\ Christopher E. Horrell \\ Center for Archaeological Research \\ Gilbert T. Bernhardt \\ Center for Archaeological Research \\ Preston W. McWhorter \\ Center for Archaeological Research \\ Lee C. Nordt \\ Center for Archaeological Research
}

Follow this and additional works at: https://scholarworks.sfasu.edu/ita

Part of the American Material Culture Commons, Archaeological Anthropology Commons, Environmental Studies Commons, Other American Studies Commons, Other Arts and Humanities Commons, Other History of Art, Architecture, and Archaeology Commons, and the United States History Commons

Tell us how this article helped you.

This Article is brought to you for free and open access by the Center for Regional Heritage Research at SFA ScholarWorks. It has been accepted for inclusion in Index of Texas Archaeology: Open Access Gray Literature from the Lone Star State by an authorized editor of SFA ScholarWorks. For more information, please contact cdsscholarworks@sfasu.edu. 


\section{An Archaeological Survey of a Pipeline Right-of-way along Loop 1604 from IH-37 to the San Antonio River, Southeast Bexar County, Texas \\ Creative Commons License \\ (c) (1) (8)}

This work is licensed under a Creative Commons Attribution-NonCommercial 4.0 International License 


\section{An Archaeological Survey of a Pipeline Right-of-way along Loop 1604 from IH-37 to the San Antonio River, Southeast Bexar County, Texas}

\section{David L. Nickels, Christopher E. Horrell, Gilbert T. Bernhardt, Preston W. McWhorter, and Lee C. Nordt}

Robert J. Hard and C. Britt Bousman

Principal Investigators

Texas Antiquities Committee Permit No. 1801

Ocopyright

Center for Archaeological Research

The University of Texas at San Antonio

Archaeological Survey Report, No. 273

1998 
The following information is provided in accordance with the General Rules of Practice and Procedure, Chapter 41.11 (Investigative Reports), Texas Antiquities Committee:

1. Type of Investigation: Survey

2. Project name: SAWS IH-37/Loop 1604 to the San Antonio River

3. County: Bexar

4. Principal investigators: Robert J. Hard and C. Britt Bousman

5. Name and location of sponsoring agency: San Antonio Water System, P.O. Box 2449, San Antonio, Texas 78298-2449

6. Antiquities Permit No.: 1801

7. Published by the Center for Archaeological Research, The University of Texas at San Antonio, 6900 N. Loop 1604 W., San Antonio, Texas 78249-0658, 1998

A list of publications offered by the Center for Archaeological Research is available. Call (210) 458-4378; write to the Center for Archaeological Research, The University of Texas at San Antonio, 6900 N. Loop 1604 W., San Antonio, Texas 78249-0658; e-mail to car@ lonestar.utsa.edu; or visit CAR's Web site at http://www.csbs.utsa.edu/ research/car/index.htm. 


\begin{abstract}
In February 1997, the Center for Archaeological Research (CAR) of The University of Texas at San Antonio was contracted by the San Antonio Water Systems (SAWS) to conduct an intensive archaeological survey and geomorphological study along a proposed $5.5-\mathrm{km}$ water main right-of-way, from the junction of IH-37 and Loop 1604 to the San Antonio River in southeast Bexar County. Upon completion of a 100-percent pedestrian survey, 10 backhoe trenches, and 152 shovel tests, CAR concluded that no significant cultural remains would be impacted by excavations for the proposed water main, and recommends that no further archaeological work is required prior to construction.
\end{abstract}




\section{Contents}

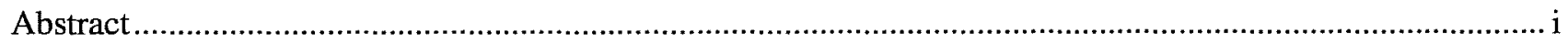

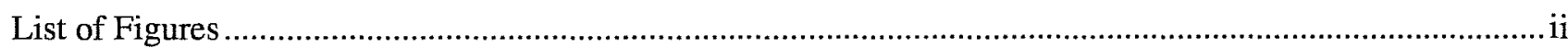

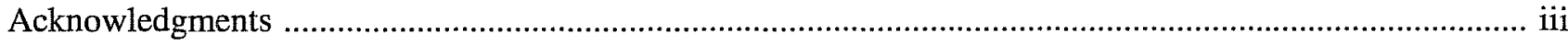

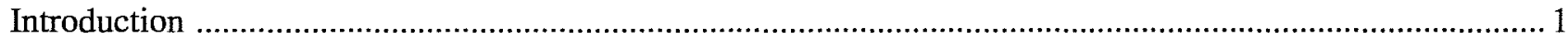

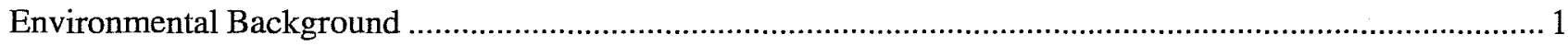

Previous Archaeological Investigations in Southeast Bexar County ........................................................ 3

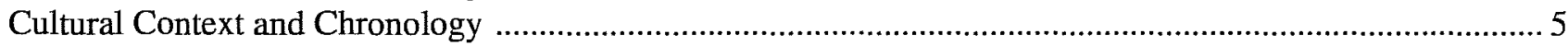

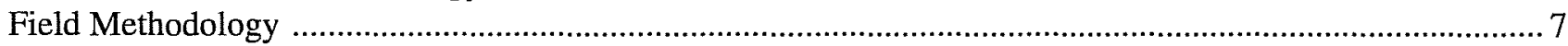

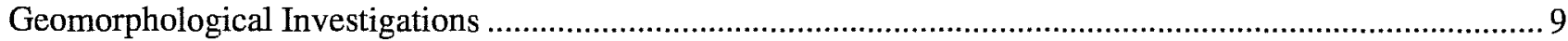

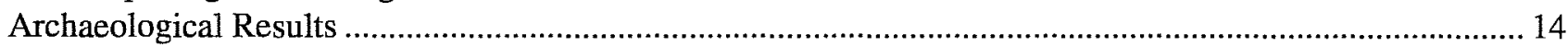

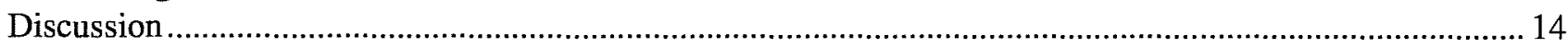

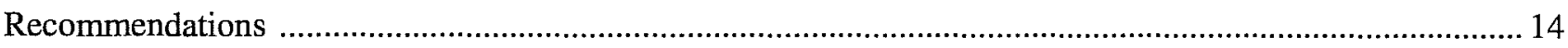

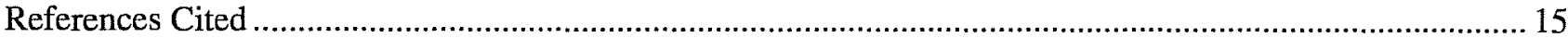

\section{Figures}

1. Current and previous archaeological projects in southeast Bexar County ...............................................2

2. Shovel tests, backhoe trenches, cutbank exposure, and disturbed areas in the project area ........................ 8

3. Terraces (T) identified along Loop 1604 from IH-37 to the San Antonio River .................................... 10 


\section{Acknowledgments}

The authors would like to thank Cindy Kovacic, P. E., director of system engineering, and Rolando H. Briones, Jr., P. E., manager of replacements and improvements, for the San Antonio Water System, for their enthusiastic cooperation, expertise, and assistance throughout the project. SAWS field crew members Jesse Medina and Barry Bonn lent their full support, and skillfully operated the backhoe for our geomorphological study. The project could not have been completed without the able fieldwork of CAR crew chief Robert R. Rector and crew members Owen Ford, Ginny Chagnon, Edgar Johnson, Richard Jones, Ricky Robinson, Kristi Miller, and Bruce Moses. Moses and Fernando Londoño contributed their expertise in cartography for this report, and as always, Marcie Renner's and Lucy Vasquez's technical support is greatly appreciated. Robert J. Hard, C. Britt Bousman, and Brett A. Houk are thanked for providing professional advice and guidance throughout the project. 



\section{Introduction}

From February 26 to March 7, 1997, the Center for Archaeological Research (CAR) of The University of Texas at San Antonio conducted an archaeological survey and geomorphological study along a proposed water main right-of-way for San Antonio Water Systems (SAWS). SAWS has committed service to areas that have had trouble with bad water wells and is spending significant resources in the south Bexar County area. To comply with the Texas Antiquities Code, which "declares that it is the public policy and in the interest of the State of Texas to locate archeological sites and other cultural resources, in, on, or under any land within the jurisdiction of the State of Texas" (Texas Natural Resource Code of 1997, Title 9, Chapter 191, Antiquities Code of Texas, Section 191.002), the archaeological survey was required for the proposed water main extending from the junction of IH-37 and Loop 1604, to the San Antonio River in southeastern Bexar County (Figure 1). The project area right-of-way was $10 \mathrm{~m}$ wide by $5.5 \mathrm{~km}$ in length. The work was performed under Texas Antiquities Permit No. 1801 .

Robert J. Hard served as principal investigator, and C. Britt Bousman as co-principal investigator. David L. Nickels served as the project director and was responsible for data collection, analysis, and report preparation. Lee C. Nordt and Gilbert T. Bernhardt from Baylor University conducted the geomorphological study. The single artifact, a core, found during the investigation was collected and is curated at the CAR laboratory. All site records, photographs, and drawings are on file at the CAR laboratory.

Road building activities, including blading and dumping, had partially disturbed the entire length of the project area, and a telephone utility trench had previously been excavated along the western four kilometers. In many areas, the proposed pipeline would cut through previously disturbed upper levels, but would also impact deeper undisturbed sediments. The research design focused on the appropriate methods for locating cultural material that could be impacted by planned construction. One hundred fifty-two shovel tests and 10 backhoe trenches were excavated along the 5.5-km right-of-way. No archaeological sites were found during the survey. Four shovel tests revealed lithic flakes which could have been culturally altered, but were suspect due to their associated context with machine-altered gravels. Additional shovel tests in those areas produced no further evidence of cultural material. One core was found in the bottom of a backhoe trench. The trench walls showed signs of disturbance and construction fill to a depth of one meter. A thorough inspection of the walls and backdirt revealed no additional cultural material.

The following sections of this report synthesize the environmental background of the project area and the previous archaeological investigations conducted there. The results of the current project, a description of the artifacts, and a synthesis and assessment of the archaeological and geomorphological data are also presented.

\section{Environmental Background}

The project area is located in southeastern Bexar County, Texas (Figure 1), lying within the NuecesGuadalupe Plain, a northern biogeographical subarea of the South Texas Plains. Adjoining the NuecesGuadalupe Plain to the east is the Gulf Coastal Plain, and beyond that is the Gulf of Mexico, approximately $224 \mathrm{~km}$ to the east. Thirty kilometers to the north, plains give way to an abrupt rise - the Balcones Escarpment and the Edwards Plateau. The Balcones Escarpment serves as a geographical division between the Central Texas archaeological region to the north and the South Texas region to the south (Black 1989a:39-41).

The climate is characterized as modified subtropical, with cool winters and hot summers (Taylor et al. 1991:118), primarily influenced by the low elevations and the Gulf of Mexico to the east. Daytime humidity ranges from 50 to 80 percent throughout the year, while clear skies prevail over 70 percent of the summer and 50 percent in winter. The coldest month is January (average temperature: $62.3^{\circ} \mathrm{F}$ ), and the hottest month is August (average temperature: $94.2^{\circ} \mathrm{F}$ ) (Taylor et al. 1991:Table 11). Rainfall averages 27.89 inches (Taylor et al. 1991:Table 11), but a great deal of variation exists from year to year, with 52.28 inches recorded in 1973 
This page has been

redacted because it

contains restricted

information. 
and 10.11 inches recorded in 1917 (McGraw and Hindes 1987:37). Light snowfalls occur every three or four years (Taylor et al. 1991:118-119). The growing season averages 275 days south of the Balcones Escarpment (Taylor et al. 1991:119), between March 1 and December 1.

The study-area ecotone incorporates an interface of diverse ecological communities (Johnson 1967:73), including Blackland Prairie, Oak-Hickory forest, and Mesquite-Chaparral Savanna. Stahle and Cleaveland (1995:55) suggest that the diversity in forest mottes was created from microenvironments existing in the late glacial period (ca. 15,000 B.P.). Blair (1950:112) notes that three biotic provinces converge in Bexar County: the Texan (eastern half of the county), the Balconian (the Edwards Plateau and Balcones Escarpment), and the Tamaulipan (southwestern county, South Texas Plain). The geographic location of the project area, essentially on the periphery of these three biotic provinces, provides a dynamic setting for a great diversity in riverine, upland, and xeric vegetation and fauna.

Two ecological settings dominate the project area landscape within the ecotone: uplands and creek zones. Descriptions of the project area prior to 1900 reveal that the uplands were once dominated by tall grasses, with occasional stands of brush and mesquite (Inglis 1964). Early descriptions (1675-1722) of plant life by pre-twentieth century observers who left a written record of the area suggest that mesquite and other thorny scrub were present in scattered mottes, while vast areas contained open grasslands with little or no brush (Inglis 1964:Plate 1). Later observers documented the change on the South Texas Plain from grassland/scrub grassland mosaic to the domination of thorny brush (Inglis 1964:Plates 1-3). By 1900 the area was described as "dense brush or chaparral" (Inglis 1964: Plate 3).

Historic alterations to the primary landscape include plowing, overgrazing, stream rechannelization, controlled burning, and the introduction of deep wells. These undoubtedly caused lower water tables and have concurrently altered the plant and animal communities.

\section{Previous Archaeological Investigations in Southeast Bexar County}

Although Bexar County is one of the most studied in the state, with over 1,300 recorded sites, the southern portion has received relatively little attention. This section provides a cursory synthesis of official surveys and recorded sites around the project area (Figure 1).

Greer (1970) documented the M. Richter and Sanger Pottery Kilns (41BX129), a historic site in the community of Elmendorf. The site consists of machinery mountings and sherds from pottery kilns dating ca. 1886-1915.

Fox (1977a) recorded a prehistoric lithic scatter (41BX226) located near the confluence of the Medina and the San Antonio rivers. Surface artifacts included Archaic and Late Prehistoric points, Guadalupe and Clear Fork tools, flakes, cores, and tools.

As a part of the San Antonio 201 Wastewater Treatment Project, CAR conducted archaeological surveys northwest of the current project area in 1977 and 1978. In 1977 survey crews examined the area immediately surrounding the Leon Creek, Rilling Road, and Salado Creek wastewater treatment plants. The area at the confluence of the San Antonio and Medina rivers was given a preliminary examination, and it was tentatively determined that the only archaeological site present was $41 \mathrm{BX} 124$. Artifacts recovered over the years by the owner indicated human occupation from the Archaic to the Late Prehistoric (Fox 1977b). Subsequent to this survey, the owner reported finding Guadalupe tools on the site which could indicate that occupation began as early as the Archaic period (Fox et al. 1978). The 1978 pedestrian surveys covered an area ca. $400 \mathrm{~m}$ long, following sewer pipeline routes linking the Leon Creek, Salado Creek, and Rilling Road sewer treatment plants to the Confluence Sewer Treatment Plant. Also surveyed was an area of 360 acres in the vicinity of the Confluence site at the junction of the San Antonio and Medina rivers (Figure 1), approximately two kilometers northwest of the current project area (Fox et al. 1978). 
41BX330 was identified along the Salado Creek Sewer Treatment Plant-Confluence site pipeline route $10 \mathrm{~cm}$ below the surface in erosional cuts and along a dirt road crisscrossing the area near a steep bank of the San Antonio River. Fire-reddened cobbles, lithic debris, and occasional lithic artifact fragments were found. A small medial biface fragment and a ceramic rim sherd tentatively identified as Goliad ware were also discovered. Along the Leon Creek Confluence right-of-way, 41BX333 was found just above the juncture of Leon and Comanche creeks. A medial biface fragment was recovered and a lithic scatter along the bluff face was found (Fox et al. 1978). Two other prehistoric sites were found along the Rilling Road Sewer Treatment Plant-Confluence site sewer pipeline right-of-way: 41BX332 consisted of a lithic scatter with several fire-reddened rocks spread over a $100-\mathrm{x}-150-\mathrm{m}$ area along the west bank of an intermittent drainage; 41BX331 consisted of a surface lithic scatter indicating a lithic workshop (Fox et al. 1978). The Confluence site intensive survey produced no new archaeological sites; however, 41BX124 was more intensively investigated. Two $50-\mathrm{x}-50$-cm units were excavated to a depths of 30 and $40 \mathrm{~cm}$. Although both units yielded sparse quantities of lithic debitage, no features or diagnostic artifacts were found and no cultural material was found below $30 \mathrm{~cm}$ (Fox et al. 1978).

In 1981 and 1984, CAR conducted pedestrian surveys across 3,539 acres for a cultural assessment of the area to be impacted by the proposed Applewhite Reservoir, approximately $16 \mathrm{~km}$ northwest of the current project area. Eighty-five historic and prehistoric sites were documented along the Medina River. The findings indicate that many cultural deposits are located within the areas where Olmos, Salado, Leon, and Medio creeks converge with the Medina River (McGraw and Hindes 1987).

In June 1982, CAR conducted a pedestrian survey and subsurface testing of 525 acres at the confluence of the Medina and San Antonio rivers on the proposed Dos Rios (formerly Confluence) Wastewater Plant property (Figure 1). Forty-five backhoe trenches were excavated. Site 41BX124 was further investigated by two backhoe trenches. No subsurface cultural deposits were discovered, but surface artifacts included one core, one large uniface, two crude bifaces, two unifacially retouched chert flakes, and one point basal fragment. Site 41BX567 was discovered during the pedestrian survey. Surface materials included chert debitage, one Perdiz point, one possible Scallorn point, and one Leon Plain sherd (Woerner 1983). 41BX567 was tested by excavation of a shovel test, which yielded lithic flakes, and two backhoe trenches, which were void of cultural material.

In January 1990, a pedestrian survey of a 110-acre tract located south of the intersection of Old Corpus Christi and Streich roads (north of the current project area) located prehistoric site 41BX843 (Figure 1). Twelve shovel tests were placed off-site in areas of poor visibility, one of which produced a flake. Twelve shovel tests were placed on site, five of which yielded cultural material. Cultural material recovered consisted of two possibly burned rocks, three unmodified chert flakes, and one chert core. Artifacts occurred between 28 and $40 \mathrm{~cm}$ below the surface (Boyd and Freeman 1990).

The Richard Beene site (41BX831) is located on the Medina River in the Applewhite Reservoir project area, northwest of the current project area. It was excavated in 1991 and further tested in 1995. The site is deeply buried in the first terrace above the Medina River. Its well-defined stratigraphy yielded artifacts and faunal remains representing a continuous occupation from Paleoindian through Late Prehistoric periods (Thoms et al. 1996).

In 1995 a pedestrian survey and subsurface testing were conducted on a $2.8-\mathrm{km}$-long, 7-m-wide SAWS pipeline right-of-way along Old Corpus Christi Road from Streich Road to Richter Road, and along Richter Road to the Southern Pacific Railroad. Fourteen shovel tests were excavated, but no cultural material was recovered (Nickels 1995).

In February 1997, CAR determined that a 4,600-mlong by $2-4-m$-wide SAWS pipeline right-of-way along side Watson, Howard, Fischer, and Quintana roads was too badly disturbed to warrant an intensive archaeological survey. CAR conducted a 100-percent pedestrian survey of an intact 300-m segment of rightof-way along Quintana and an intact 700-m segment 
along Fischer Road. Five backhoe trenches and 10 shovel tests were excavated. No cultural artifacts or features were encountered (Ford and Houk 1997).

\section{Cultural Context and Chronology}

Hester (1995) reviewed the archaeological and palynological evidence for south Texas and offers approximate dates for human occupation from the Paleoindian through Historic periods. The following dates and discussion are primarily derived from this most recent work. All dates are approximate and given as "before present"' (B.P.), i.e., before 1950.

\section{Paleoindian}

This phase spans the period between ca. $11,200-8800$ B.P. Diagnostic artifacts include Clovis and Folsom projectile points. The distribution of Clovis-type points across most of North America and even into Central America suggests a wide dispersal of the people who made them (Kelly 1993; Wenke 1990:201). Other artifacts associated with the Clovis culture include bifaces, prismatic blades, engraved stones, bone and ivory points, stone bolas, ochre, and shaft straighteners.

In general, the Paleoindian adaptation has been considered to be one of small bands of nomadic, big-game hunters following herds of mammoth, mastodons, bison, camel, and horse across North America (Black 1989b). More recently, emphasis has been on the wide diversity of plants and animals used for subsistence by these early Americans (Black 1989b; Hester 1983), such as turtles, tortoises, alligators, mice, badgers, and raccoons (Collins 1995:381), although they undoubtedly hunted the large animals as well (Dibble and Lorrain 1968). Known Clovis site types include killsites, quarries, caches, open campsites, ritual sites, and burials (Collins 1995:381-383; Hester 1995:433-436).

Most Paleoindian finds in central and south Texas have consisted of surface lithic scatters on upland terraces and ridges (Black 1989b:25, 48). Many Paleoindian points have been recovered from surface contexts in Bexar and nearby counties (Chandler and Hindes 1993; Hester 1968a, 1968b; Howard 1974).

\section{Early Archaic}

Hester (1995:436-438) dates the Early Archaic from $8800-4500$ B.P. in south Texas. In general, more intensive exploitation of local resources in central Texas-such as deer, fish, and plant bulbs-is indicated by more ground-stone artifacts, fire-cracked rock cooking features, and more specialized tools such as Clear Fork and Guadalupe bifaces (Turner and Hester 1993:246,256). Weir (1976) speculates that Early Archaic groups were small and highly mobile, inferred from the fact that Early Archaic sites are thinly distributed and that diagnostic types are seen across a wide area, including most of Texas and northern Mexico.

\section{Middle Archaic}

Hester (1995:438-441) relies on Hall et al. (1986) to define this intermediate interval of the Archaic as lasting from about $4500-2300$ B.P. in south Texas. The Middle Archaic appears to have been a time of increased population, based on the large number of sites from this period in south and central Texas (Story 1985:40; Weir 1976:125,128). On the South Texas Plains, exploitation of widely scattered, year-round resources such as prickly pear continued (Campbell and Campbell 1981:13-15), as did hunting deer and rabbit.

The common presence of deer remains in burned rock middens encourages the view that deer processing was very much a part of the work at these sites (Black and McGraw 1985:278; Weir 1976:125). Bison bone is encountered in archaeological sites in central and south Texas, at least occasionally, during all but the earliest part of the Middle Archaic (Dillehay 1974).

\section{Late Archaic}

Hester (1995:441-442) dates the final phase of the Archaic to approximately $2300-1300$ B.P. Subsistence is assumed to have become less specialized and focused on acorns, in favor of a broad spectrum subsistence base (Black 1989a:30). By about 1450 B.P., bison had again disappeared (Dillehay 1974). 
The proliferation of distinguishable human cemeteries has been attributed to this period, with the earliest occurrences dating to the south Texas Middle Archaic (Hester 1995:439-440). Although inhabitants of the South Texas Plain near Brownsville and Rockport had begun to make pottery by about 1750 B.P., the northern part of the plain was still "pre-ceramic" until 1,000 years later (Story 1985:45-47). Late Archaic points tend to be much smaller than Middle Archaic points. The most common are Ensor and Frio types (Turner and Hester 1993:114,122), both of which are short, triangular points with side notches. The Frio point also has a notched base (Turner and Hester 1993:122).

\section{Late Prehistoric}

Hester (1995:442-449) recognizes that the commonly used date of 1200 B.P. for the end of the Archaic in south Texas is arbitrary. A series of distinctive traits marks the transition from the Archaic to the Late Prehistoric period, including the technological shift to the bow and arrow and the introduction of pottery to central Texas and the northern South Texas Plain (Black 1989a:32; Story 1985:45-47). Settlement shifts into rockshelters have been noted (Shafer 1977; Skinner 1981). Cemeteries from this period often reveal evidence of conflict (Black 1989a:32).

Beginning rather abruptly at about 650 B.P., a shift in technology occurred. This phase is characterized by the presence of blade technology, the first ceramics in central Texas (bone-tempered plainwares), the change to Perdiz arrow points, and alternately beveled bifaces (Black 1989a:32; Huebner 1991:346). Steele and Assad Hunter (1986) argue for the occurrence of a distinct change in diet between the Late Archaic and the Late Prehistoric components in two sites in Choke Canyon Reservoir in south Texas. Analysis of the number of identified specimens (NISP) shows a marked increase in artiodactyl elements present during the late Late Prehistoric, an increase largely due to the addition of bison to the "menu" (Steele and Assad Hunter 1986:468). The only archaeological evidence that domesticated plants were ever introduced in south or central Texas is a single corncob found in Late Prehistoric context in Timmeron Rock Shelter (Harris 1985). This single cob is not enough to postulate there was ever a significant presence of maize in the area. Only the arrival of the Spanish brought significant cultivars to south and central Texas.

\section{Historic Period}

The end of the Late Prehistoric and beginning of the Historic period in both central and south Texas can be characterized by written accounts of European contact with indigenous groups. Collins (1995:386-387) offers that the Historic period then begins ca. 260 B.P. in central Texas. However in south Texas, Hester (1995:450-451) agrees with Adkins and Adkins (1982:242) when he suggests that the indigenous groups may have been affected by European influence but we are only able to observe the materials in the archaeological record because the written accounts simply are not available. He would rather label this largely unknown period "Protohistoric."

The cultural context for the historic groups in the area of study is largely conditioned by the presence of outside ethnic groups and regional power struggles. The numerous small groups of Coahuiltecans encountered by the early explorers and later Spanish intrusions are addressed in many sources (Campbell 1983; Campbell and Campbell 1985; Hester 1989; John 1975; Newcomb 1961; Swanton 1952). The various later intrusive groups, such as Tonkawa, Lipan Apache, and Comanche, are also described by numerous researchers (Ewers 1969; Hester 1989; Jones 1969; Kelley 1971; Newcomb 1961, 1993; Sjoberg 1953a, 1953b).

At the beginning of the seventeenth century, many south Texas Indian groups were being pushed northward by continual Spanish expansion. By the mid-seventeenth century, a new pressure on the Indians indigenous to the area began to be applied from the northern nomadic group, the Apache. The Apache were adapted to a more Plains-lifeway style of bison hunting, especially once they acquired horses from the Spaniards (Campbell and Campbell 1985:27). Later, the Apaches were displaced by another group of nomadic, bison-hunting Indians-the Comanchesfrom the High Plains of Texas (Campbell 1991:111). 
Warfare with intrusive Native American groups, migration, demoralization, inner-group conflict, disease, and death fragmented the indigenous Indian groups, and forced continual mixing and remixing among them (Bolton 1915; Campbell 1991:345; León et al. 1961). Most of the native languages have been lost, although recent attempts at reconstruction are enlightening (e.g. Johnson 1994; Johnson and Campbell 1992). The establishment of Spanish missions along the San Antonio River in the late 1600s and early 1700 s induced many groups to seek the relative comfort, protection, and seemingly peaceful coexistence offered by the Spanish missionaries (Campbell and Campbell 1985; Chipman 1992; de la Teja 1995; Habig 1968a, 1968b; Hard et al. 1995; Inglis 1964). Although fear of the invading Apache and Comanche pressured many of the Indians to seek the protection of missions, they were now exposed to the exploitation of the Spanish (Campbell 1991:346347).

Few landowners dared to live on their outlying lands until about 1749 , when a treaty with the Apaches brought peace for a while (de la Teja 1995:100). The Apache, pushed southward by the invading Comanche who had moved into the hill country of central Texas, continued to range over the area between San Antonio and Laredo until the early 1800s (Campbell and Campbell 1985:27). Weary of warfare with the Comanche, a few Apache began to seek asylum in the missions (McGraw and Hindes 1987:367; West 1904:50).

In the autumn of 1785 , a peace treaty was agreed to in Santa Fe between the Don Juan Bautista de Anza, representing the Spanish Crown, and Cuera (Leather Jacket), representing the Comanches. The treaty signaled the opening of a period of peaceful coexistence in what is today Bexar County, during which Comanches brought hides, meat, and tallow to San Antonio to trade for goods and services not available elsewhere, such as blacksmithing and gun repair (Fehrenbach 1978:221-224; Poyo and Hinojosa 1991:125-126). The few Comanches who entered the missions were apparently women and children who were captured during punitive raids by Spanish soldiers (Campbell and Campbell 1985:26).
The newly formed government of Texas gave land grants that were large, consisting of around 5,000 acres for each property, and Spanish cattle ranching became prevalent south and southeast of San Antonio (Jackson 1986). However the political turmoil that permeated early Texas caused the near-complete European desertion of San Antonio following the Mexican War for Independence (Fehrenbach 1983).

Around 1840, settlers from Germany and Alsace-Lorraine and from other regions of the United States began to flood into San Antonio. Many of the Germans moved into the hill country to the north, settling into communities, and raised sheep or cattle (Freeman 1994:5-9). As the sheep and cattle markets emerged in the 1880s, ranchers and farmers settled farther away from San Antonio (Flanagan 1974; Lehmann 1969; Nickels et al. 1998). The introduction of twentiethcentury technologies such as mills and improved methods of production have shaped the area as it exists today (Fox et al. 1989).

\section{Field Methodology}

Following a 100-percent pedestrian survey, 10 backhoe trenches and 152 shovel tests were excavated. Testing began at the intersection of IH-37 and Loop 1604 and followed a $5.5-\mathrm{km}$ route along the proposed water line right-of-way adjacent to Loop 1604, ending at the San Antonio River (Figure 2). Surface visibility in the project area ranged from 0-25 percent due to brush and grasses. Areas of high disturbance due to blading, road-building activities, and trenching for fiber optic lines were not tested (Figure 2). These areas of disturbance totaled approximately $424 \mathrm{~m}$ in length.

Archaeologists also monitored the excavation of geomorphological trenches placed selectively along the proposed right-of-way. The trenches measured two meters in depth and were five meters in length.

Systematic shovel tests were conducted to determine the presence of subsurface cultural material. Shovel tests were conducted at $50-\mathrm{m}$ intervals from the intersection of IH-37 and Loop 1604 to Labus Road (Figure 2). East of Labus Road, the shovel testing interval was reduced to $30 \mathrm{~m}$ because of a higher probability 


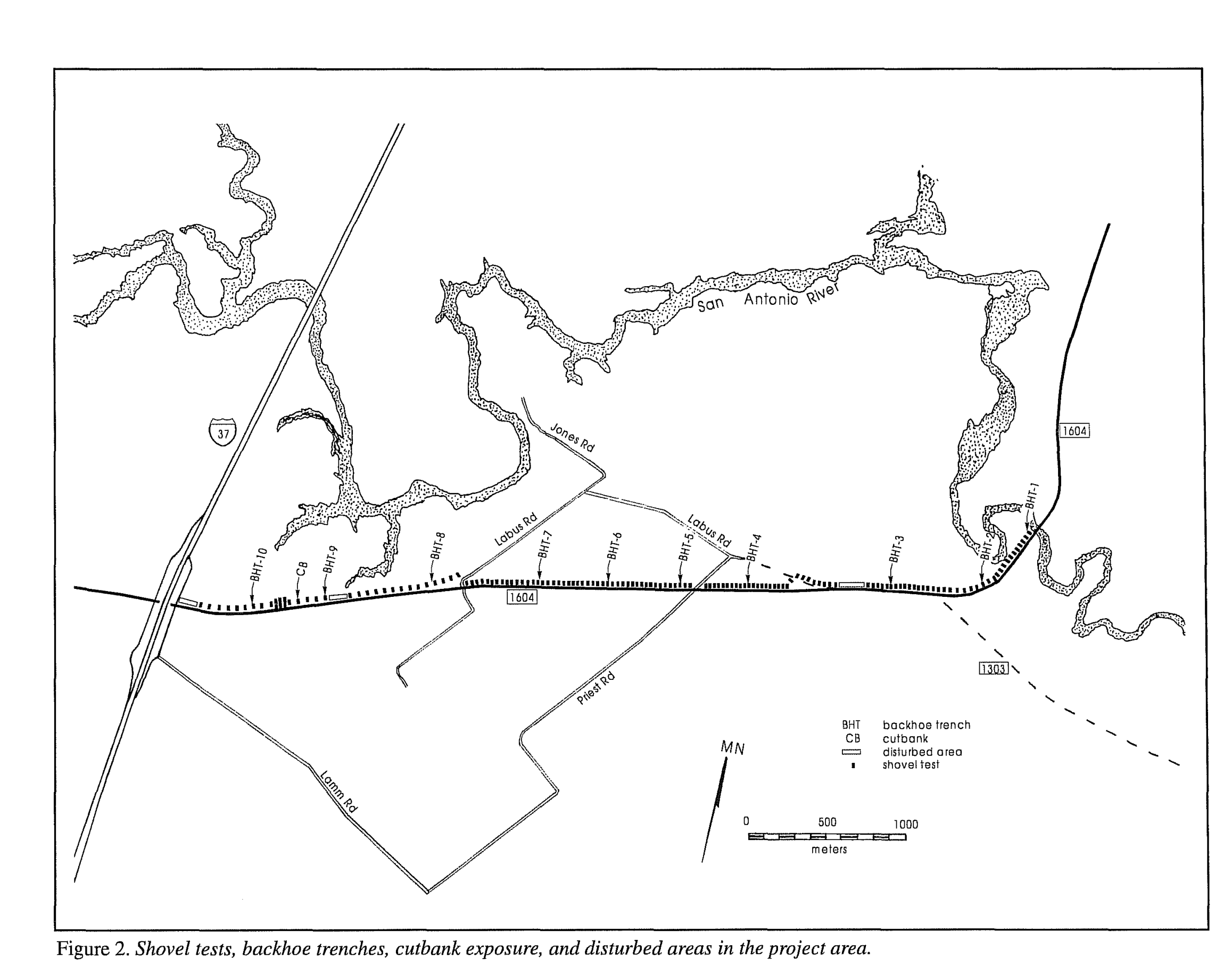


for encountering cultural materials in the San Antonio River terraces (Figure 2). All shovel tests were approximately $30 \mathrm{~cm}$ in diameter and excavated in $10-\mathrm{cm}$ levels to a maximum depth of $50 \mathrm{~cm}$. All sediments were screened through $1 / 4$-inch steel mesh.

In addition, archaeologists periodically monitored trenching operations and examined backfill dirt for cultural material. Finally, as part of an on-going research effort at $\mathrm{CAR}$, raw material samples were collected for use in comparative studies and X-ray microfluorescence studies involving lithic sourcing for the region.

\section{Geomorphological Investigations}

\section{Introduction}

The study area is located in a Quaternary alluvial setting of the San Antonio River, about $6.4 \mathrm{~km}$ downstream from the confluence of the Medina and the San Antonio rivers (Figure 1). The San Antonio River basin mainly drains shales, siltstones, sandstones, and limestones of the Upper Cretaceous; and mudstones, clays, and sands of the early Tertiary. The Medina River drains shales, siltstones, sandstones, and limestones of the Lower and Upper Cretaceous; and mudstones, clays, and sands of the early Tertiary. Formations from these geologic units have contributed mostly clays, sands, and gravels to the alluvial valley since early Pleistocene to recent. The objectives of the geoarchaeological investigation were to: 1) delineate spatially and chronologically alluvial environments of deposition, and 2) assess the influences of these environments on the spatial and temporal distribution of the archaeological record.

\section{Methods}

The late Quaternary alluvial record of the San Antonio River within the study area was constructed from 10 backhoe trenches and one cutbank exposure; the 1992 Losoya and Saspamco 7.5 minute USGS quadrangle topographic maps; the Geologic Atlas of Texas, San Antonio Sheet (Barnes 1983); and the Soil Survey of Bexar County, Texas (Taylor et al. 1991). The selected study localities are shown in Figure 2. The alluvial stratigraphic chronology was based on the degree of soil development, topographic location, and correlation to other central Texas alluvial stream histories.

\section{Alluvial Stratigraphy}

Four late Quaternary landforms are mapped on the south side of the San Antonio River in the area: a terrace (T3), two flood terraces (T2 and T1) and the floodplain (T0) (Figure 3). The T3 and T2 terraces are dissected by erosion from modern gullies and tributaries. Associated with these landforms are general alluvial lithologic facies: a fine-grained flood basin phase (f) and a colluvial/alluvial channel fill phase ( $n$ ). These facies define the unconformably bound stratigraphic units or those contacts marked by erosion and non deposition.

\section{Terrace 3}

\section{Lithology}

Terrace 3 (T3) is situated about $23 \mathrm{~m}$ above the modern low-water channel of the San Antonio River (Figure 3). The soil exposed in BHT-10 developed into the colluvial/alluvial fill of Unit T3-n. It consists of a dark yellowish brown, non-calcareous, loamy fine sand upper surface horizon over a dark yellowish brown non-calcareous loamy fine sand lower surface horizon. The surface horizons were probably disturbed during road construction.

The lower surface horizon overlies a brown sandy clay loam Bt upper subsoil horizon and a very pale brown $\mathrm{Btk}$ lower subsoil horizon. Pedogenic $\mathrm{CaCO}_{3}$ nodules occur between 43 and $200 \mathrm{~cm}$, with a maximum accumulation of 10 percent from $89-200 \mathrm{~cm}$. Yellowish red mottles occur between 43 and $200 \mathrm{~cm}$ and increase between $43 \mathrm{~cm}$ and $89 \mathrm{~cm}$.

The soils in BHT-9 and BHT-5 developed in finegrained flood deposits of Unit T3-f. At BHT-9 the surface horizon consists of a light yellowish brown loam disturbed by road construction. It overlies a very pale brown sandy loam Bk1 horizon; a very pale 


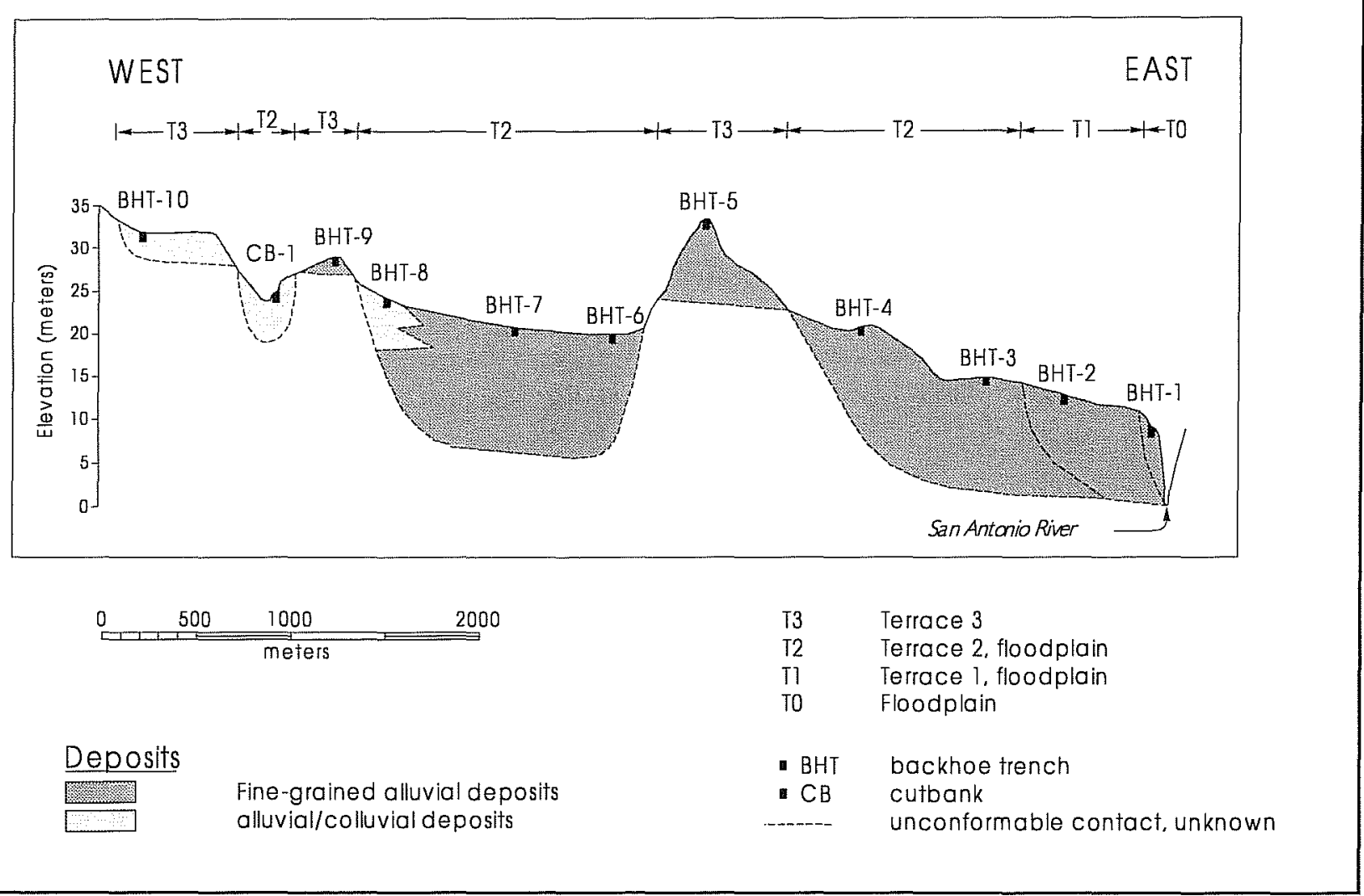

Figure 3. Terraces (T) identified along Loop 1604 from $1 H-37$ to the San Antonio River.

brown, sandy clay loam, Bk2 horizon; and a very pale brown, sandy loam, $\mathrm{Bk} 3$ horizon. Pedogenic $\mathrm{CaCO}_{3}$ nodules and masses occur between 51 and $135 \mathrm{~cm}$, with a maximum accumulation of 50 percent occurring between 51 and $86 \mathrm{~cm}$. About 40-50 percent of the $\mathrm{Bk} 3$ horizon contains poorly sorted, grain-supported, and subrounded limestone and silicious gravels. The $\mathrm{B}$ horizons overlie a pale red, sand $\mathrm{C} 1$ horizon and a strong brown, sand $\mathrm{C} 2$ horizon. $\mathrm{A}$ few $\mathrm{CaCO}_{3}$ masses and nodules occur in the $\mathrm{C} 1$ horizon between 135 and $168 \mathrm{~cm}$. The $\mathrm{C} 2$ horizon contains about 5 to 10 percent, moderately sorted, rounded limestone gravels.

BHT-5 is located on the highest topographic elevation along the study profile, about $32 \mathrm{~m}$ above the modern low-water channel of the San Antonio River. The upper surface horizon is a dark brown, sandy loam horizon over a black, sandy clay loam Ab horizon. Both surface horizons contain a few filaments of $\mathrm{CaCO}_{3}$. The surface horizons overlie a brown, sandy clay loam, $\mathrm{Bw}$ subsoil horizon; a pale brown, clay loam, Bk1 subsoil horizon; and a very pale brown, clay loam,
Bk2 subsoil horizon. Pedogenic $\mathrm{CaCO}_{3}$ nodules, masses, and filaments occur between 40 and $200 \mathrm{~cm}$, with a maximum accumulation of 25 percent occurring between 87 and $163 \mathrm{~cm}$.

The soils in BHT-10 developed near the southern margin of T3. This determination is based on their geomorphic position next to the Wilcox outcrop. The soils seem to be composed of a mixture of colluvial material supplied from the nearby Carrizo and Wilcox questa and from overbank or flood deposits from the ancestral San Antonio River. Gravel deposits found in BHT-9 are probably contemporaneous with T3 deposition and were supplied by an ancestral tributary stream of the San Antonio River.

The gravel deposits also indicate that during this time, fine-grained sediment supply was greatly diminished, and transport capacity was high, resulting in incision of upstream limestone bedrock valleys. This was due to either an increase in flow or a change in base level of the San Antonio River. Deposits found at BHT-9 
and BHT-5 coarsen downward and indicate flood or overbank deposits on relatively stable point bar nodes.

\section{Chronology}

The numerical age of T3 is unknown; however, its elevation and degree of soil development (dense accumulation of pedogenic $\mathrm{CaCO}_{3}$ nodules and masses) suggest that the terrace is probably late Pleistocene in age. T3 may be correlative to the late Pleistocene Eagle Lake Alloformation studied by Blum and Valastro (1994) on the lower Colorado River basin of the Gulf Coastal Plain. Also, T3, although not stacked sequentially, may be correlative in age to the late Pleistocene fauna sequence found in the Medina River Applewhite Terrace (Thoms et al. 1996).

\section{Terrace 2}

\section{Lithology}

Terrace 2 (T2) is situated about $20 \mathrm{~m}$ above the modern low-water channel of the San Antonio River (Figure 3). The soils at BHT-7, BHT-6, BHT-4, and BHT-3 were developed on southward-pointing meander loops near the southern margin of $\mathrm{T} 2$ (Figure 3 ). The lithologic facies at both locations indicate fine-grained alluvial flood basin deposits in the upper section of this unit (T2-f) from the ancestral San Antonio River.

At BHT-7, two disturbed surface horizons unconformably overlie a buried lower surface horizon. The upper surface horizon is a dark grayish brown clay loam, and the lower surface horizon is a dark gray clay loam. The buried lower surface horizon overlies a brown, sandy clay loam, Bwb upper subsoil horizon; and a pale brown, sandy clay loam, Bkb lower subsoil horizon. Pedogenic $\mathrm{CaCO}_{3}$ filaments and nodules occur between 62 and $200 \mathrm{~cm}$ with a maximum accumulation of five percent occurring between 105 and $200 \mathrm{~cm}$.

At BHT-6, a brown, slightly calcareous, clay upper surface horizon; a brown, slightly calcareous, clay middle surface horizon; and a grayish brown, slightly calcareous, clay lower surface horizon overlie a buried dark gray, slightly calcareous, clay horizon. The three surface horizons appear to be disturbed by road construction. The buried horizon is over a gray, moderately calcareous, clay loam, Bgb subsoil horizon. $\mathrm{CaCO}_{3}$ filaments and nodules were not visible in the profile.

At BHT-4, a disturbed, brown, sandy clay loam surface horizon overlies a grayish brown, sandy clay, Bk1 upper subsoil horizon and a light yellowish brown, clay, $\mathrm{Bk} 2$ lower subsoil horizon. Pedogenic $\mathrm{CaCO}_{3}$ nodules occur between 27 and $200 \mathrm{~cm}$, with a maximum accumulation of five percent occurring between 27 and $97 \mathrm{~cm}$. At BHT-3, two disturbed surface horizons-a dark grayish brown, slightly calcareous, clay loam upper surface horizon and a very dark gray, slightly calcareous, clay loam lower surface horizon - unconformably overlie a buried, grayish brown, slightly calcareous, clay loam, horizon. The buried horizon overlies a brown, clay loam, Bwb upper subsoil horizon and a dark grayish brown, clay loam, $\mathrm{Bkb}$ lower subsoil horizon. Pedogenic $\mathrm{CaCO}_{3}$ filaments and nodules occur between 35 and $200 \mathrm{~cm}$ with a maximum accumulation of five percent occurring between 99 and $200 \mathrm{~cm}$.

Unit T2-n occurs at two localities on T2: CB-1 and BHT-8. At CB-1, Unit T2-n is truncated and buried by $125 \mathrm{~cm}$ of Historic deposits. The erosional unconformity overlies a yellowish brown, calcareous, sandy loam, Bwb upper subsoil horizon and a brownish yellow, sandy loam, Bkb lower subsurface horizon. Pedogenic $\mathrm{CaCO}_{3}$ masses and nodules were not present in the upper subsurface horizon. About 10 percent carbonate masses were visible in the lower subsurface horizon below the unconformity. Up to 40 percent siliceous and limestone gravel also occur in the lower subsurface horizon.

The matrix-supported subrounded gravels are poorly sorted and up to five centimeters in length along their long axis. At BHT-8 of T2-n, the brown loam upper surface horizon and the lower yellowish brown sandy loam surface horizon were highly disturbed by road construction. Gravel-size asphalt chunks were observed down to a depth of $85 \mathrm{~cm}$ through both surface horizons. The lower surface horizon unconformably overlies a yellowish brown, sandy clay loam, Bk1b 
upper subsoil horizon; a yellowish brown, clay loam, $\mathrm{Bk} 2 \mathrm{~b}$ middle subsoil horizon; and a yellowish brown, clay, $\mathrm{Bk} 3 \mathrm{~b}$ lower subsoil horizon. Pedogenic $\mathrm{CaCO}_{3}$ nodules and masses occur between 85 and $200 \mathrm{~cm}$, with a maximum accumulation of 10 percent occurring between 134 and $166 \mathrm{~cm}$. Poorly sorted, grainsupported and subrounded siliceous and limestone gravels (up to eight centimeters along their long axis) occur in the subsurface horizons with a maximum accumulation of 50 percent occurring between 134 and $166 \mathrm{~cm}$.

The fine-grained soils at BHT-7, BHT-6, BHT-4, and BHT-3 suggest they were developed on overbank or flood deposits from the meandering ancestral San Antonio River. Sediment supply exceeded transport capacity of the stream, due to either a decrease in slope or a decrease in stream flow, resulting in deposition of $\mathrm{T} 2$ and lateral migration, due to increased sinuosity, of the ancestral San Antonio River. At the time of deposition of sediments at BHT-7, BHT-6, BHT-4, and BHT-3, the San Antonio River was meandering near the south margin of the floodplain (Figure 3). Gravel deposits found at CB-1 and BHT- 8 are probably contemporaneous with T2 deposition and were supplied by an ancestral drainage to the San Antonio River.

\section{Chronology}

The numerical age of T2 is unknown. However, its elevation and degree of soil development (moderate accumulation of pedogenic $\mathrm{CaCO}_{3}$ nodules and masses) suggest that the terrace is probably early to middle Holocene in age. T2 may be geomorphically correlative to the early Holocene Columbus Bend Allomember 1 described by Blum and Valastro (1994). Also, T 2, although not stacked sequentially, may be correlative in age to the early Holocene Perez, Elm Creek, and Medina Components found in the Medina River Applewhite Terrace (Thoms et al. 1996).

\section{Terrace 1}

\section{Lithology}

Terrace 1 (T1) is situated about $15 \mathrm{~m}$ above the modern low-water channel of the San Antonio River (Figure 3). The soil at BHT-2 developed in fine-grained alluvial overbank or flood deposits (T1-f) from the ancestral San Antonio River. At BHT-2, a disturbed, slightly calcareous, dark brown, clay loam surface horizon overlies a brown, clay loam, Bw1 upper subsoil horizon and a brown, clay, Bk2 lower subsoil horizon. Less than one percent pedogenic $\mathrm{CaCO}_{3}$ filaments and nodules occur between 41 and $200 \mathrm{~cm}$.

\section{Chronology}

The numerical age of T1 is unknown; however, its elevation and degree of soil development (slight accumulation of pedogenic $\mathrm{CaCO}_{3}$ nodules and masses) suggest that the terrace is probably late Holocene in age. Between 5000 and 3000 B.P. a brief period of channel erosion occurred in many streams throughout central Texas (Blum and Valastro 1989; Nordt 1992, 1995). This may have led to the abandonment of the $\mathrm{T} 2$ floodplain and creation of the T1 valley. Ongoing sedimentation and lateral migration of the San Antonio River created the T1 terrace. Lithologically this indicates a shift in hydrological regime to a fine-grained meanderbelt sometime in the late Holocene, similar to the channel type that deposited Unit T3-f in late Pleistocene and Unit T2-f in early to middle Holocene.

T1 may be geomorphically correlative to the late Holocene Columbus Bend Allomember 2 described by Blum and Valastro (1994). In addition, T2 may be correlative in age to the late Holocene Leon Creek Components found in the Medina River Applewhite Terrace (Thoms et al. 1996). 


\section{Terrace 0}

Lithology

Terrace 0 (T0) is situated about nine meters above the modern low-water channel of the San Antonio River (Figure 3). The soil at BHT-1 was developed on finegrained alluvial overbank or flood deposits (T0-f) from the San Antonio River. At BHT-1, two disturbed surface horizons - a brown, clay loam, upper surface horizon and a light brownish gray, clay loam, lower surface horizon - overlay a buried, brown, clay loam, horizon. The buried horizon overlies several brown to light yellowish brown, sandy clay loam and loam, Bwb subsoil horizons. Less than one percent pedogenic $\mathrm{CaCO}_{3}$ filaments and nodules occur between 56 and $200 \mathrm{~cm}$. Apparently, a brief period of channel erosion was followed by continual finegrained aggradation during the last 1,000 years.

\section{Chronology}

The numerical age of T0 is not known. However, its elevation and degree of soil development (very slight accumulation of pedogenic $\mathrm{CaCO}_{3}$ nodules and masses) suggest that the terrace is probably very late Holocene to Modern in age. T0 may correlate geomorphically to the late Holocene Columbus Bend Allomember 3 described by Blum and Valastro (1994).

\section{Geoarchaeology}

\section{Terrace 3}

T3 contains two stratigraphic facies: 1) an alluvial/ colluvial facies at BHT-10; and 2) fine-grained floodplain deposits at BHT-5. The two units have been tentatively dated by elevation and soil development older than 10,000 B.P. A few chipped stone flakes were found on the surface near BHT-10 and BHT-5. The flakes may have been transported by overwash from nearby slopes outside the project area. T3 could contain portions of the Paleoindian records in the finegrained alluvial floodplain (T3-f) and alluvial/colluvial
(T3-n) deposits. The surface of T3 may contain assemblages of sites spanning Paleoindian to present.

\section{Terrace 2}

T2 contains two stratigraphic facies: 1) fine-grained floodplain deposits at BHT-7, BHT-6, BHT-4, and BHT-3; and 2) alluvial/colluvial deposits found at CB1 and BHT-8. The two units have been tentatively dated by elevation and soil development as early to middle Holocene. A lithic core was found at the bottom of BHT-8. The core was not found within a primary context and was probably dislodged by trenching. $\mathrm{CaCO}_{3}$ pendants found on the core suggest it is old and was probably associated with gravel deposits found in the backhoe trench. However, it is possible that the core was transported from another site before burial. T2 could contain portions of the Paleoindian and Early Archaic records in the fine-grained alluvial floodplain (T2-f) and alluvial/colluvial (T2-n) deposits. The surface of T2 may contain assemblages of sites spanning Early Archaic to present.

\section{Terrace 1}

T1 contains one stratigraphic facies, a fine-grained floodplain (T1-f) deposit found at BHT-2. This unit has been tentatively dated by elevation and soil development to late Holocene. No artifacts were found on T1. Terrace 1 could contain portions of the Middle Archaic and Late Archaic.

\section{Terrace 0}

Terrace 0 contains one stratigraphic facies, a finegrained flood basin deposit found at BHT-1. This unit has been tentatively dated by elevation and soil development between very late Holocene to Modern in age. No cultural artifacts were found on T0. This unit could contain portions of the late Prehistoric and Historic records in the fine-grained alluvial floodplain (T0-f) deposits. The surface of T0 may contain assemblages of sites spanning late Prehistoric to present. 


\section{Archaeological Results}

No archaeological sites were revealed during the survey or testing. Four shovel tests (STs 41, 69, 85, and 92) each contained a possible cultural interior flake. The flakes were collected and, under closer examination in the CAR laboratory, were found to have been machine crushed. Although the tests were over $200 \mathrm{~m}$ from each other, and evidence of machinerycrushed gravels was prevalent, the CAR staff returned to the site and conducted two additional shovel tests at each of the positive shovel test locations. No cultural material was recovered from these additional shovel tests.

A core was recovered from BHT-4. It is a sevencentimeter-long, multidirectional, chocolate-brown chert core. The core has heat spawls and a heavy patina, interrupted by post-depositional flake scars, and 10 percent cortex. The core was found in the bottom of a geomorphological backhoe trench and therefore its exact provenience is problematic. However, disturbance of the upper one meter of sediment due to previous trenching and infilling operations was evident in the trench profile.

\section{Discussion}

Although no archaeological sites were located during this project, the 10 backhoe trenches, provided valuable information pertaining to the changing prehistoric landscape of the San Antonio River valley in southeastern Bexar County. The surveys and site investigations described in the Previous Archaeological Investigations section of this report, combined with the current project's geoarchaeological investigations, suggest a high potential for sites in southeastern Bexar County, particularly in riverine environments.

The stratigraphic record of the San Antonio River conditions the spatial and temporal distribution of the archaeological record, whereas environments of deposition influence site forming process and preservation potentials. Accordingly, the Paleoindian record may be deeply stratified within Units T3-n and T3-f, the Early Archaic within Units T2-f and T2-n, the Middle to Late Archaic within Unit T1-f, and late Prehistoric and Historic within Unit T0-f (Figure 3). Also, the preservation potential will be greatest in the fine-grained alluvial and alluvial/colluvial facies mentioned above.

The degree of surface disturbance from construction activity along Loop 1604 in the study area and the absence of exposures limits geoarchaeological interpretations. However, undisturbed surfaces on T3 and T2 may contain sites spanning Paleoindian to present. Also, undisturbed surfaces on $\mathrm{T} 1$ may comprise sites spanning Middle Archaic to present, and undisturbed sites on T0 might contain sites spanning late Prehistoric to present.

Dating terraces along the San Antonio River based on the degree of soil development, topographic location, and correlation to other central Texas alluvial stream histories is problematic. Future studies should incorporate radiocarbon dating along with more detailed soil-stratigraphic descriptions along the San Antonio River to elucidate and expand upon archaeological research and geoarchaeological theories.

\section{Recommendations}

Based on a 100-percent pedestrian survey, 10 backhoe trenches, and 152 shovel tests, CAR concludes that no cultural material will be impacted by excavations for the proposed water main. Due to the minimal recovery of cultural material within the project area, it is recommended that no additional archaeological testing is required prior to the construction. 


\section{References Cited}

Adkins, L., and R. A. Adkins

1982 A Thesaurus of British Archaeology. David and Charles, London.

Barnes, V. E.

1983 Geologic Atlas of Texas: San Antonio Sheet. Bureau of Economic Geology, The University of Texas at Austin.

Black, S. L.

1989a Environmental Setting. In From the Gulf Coast to the Rio Grande: Human Adaptation in the Central, South, and Lower Pecos Texas, edited by T. R. Hester, S. L. Black, D. G. Steele, B. W. Olive, A. A. Fox, K. J. Reinhard, and L. C. Bement, pp. 5-16. Research Series No. 33. Arkansas Archeological Survey, Fayetteville.

1989b Central Texas Plateau Prairie. In From the Gulf Coast to the Rio Grande: Human Adaptation in the Central, South, and Lower Pecos Texas, edited by T. R. Hester, S. L. Black, D. G. Steele, B. W. Olive, A. A. Fox, K. J. Reinhard, and L. C. Bement, pp. 17-38. Research Series No. 33. Arkansas Archeological Survey, Fayetteville.

Black, S. L., and A. J. McGraw

1985 The Panther Springs Creek Site: Cultural Change and Continuity in the Upper Salado Creek Drainage, South-Central Texas. Archaeological Survey Report, No. 100. Center for Archaeological Research, The University of Texas at San Antonio.

Blair, W. F.

1950 The Biotic Provinces of Texas. Texas Journal of Science 2(1):93-117.

Blum, M. D., and S. Valastro, Jr.

1989 Response of the Pedernales River of Central Texas to Late Holocene Climatic Change. Annals of the Association of American Geographers 79:435-456.

1994 Late Quaternary Sedimentation, Lower Colorado River, Gulf Coastal Plain of Texas. Geological Society of America Bulletin 106:1002-1016.

Bolton, H. E.

1915 Texas in the Middle Eighteenth Century: Studies in Spanish Colonial History and Administration. Volume 3, University of California publications in history. University of California, Berkeley.

Boyd, D. K., and M. D. Freeman

1990 Archaeological Survey of a Proposed Aluminum Rolling Mill Plant in Southeastern Bexar County, Texas Series. Prewitt, Austin.

Campbell, T. N.

1983 Coahuiltecans and their Neighbors. In Handbook of North American Indians Volume 10: Southwest, edited by A. Ortiz, pp. 343-358. Smithsonian Institution, Washington, D. C.

1991 Coahuiltecans and Their Neighbors. In Ethnology of the Texas Indians, edited by T. R. Hester. Spanish Borderlands Sourcebooks 7. Garland, New York. 
Campbell, T. N., and T. J. Campbell

1981 Historic Indians of the Choke Canyon Reservoir and Surrounding Area, Southern Texas. Choke Canyon Series, No. 1. Center for Archaeological Research, The University of Texas at San Antonio.

1985 Indian Groups Associated with Spanish Missions of the San Antonio San Antonio Missions National Historical Park. Special Report, No. 16. Center for Archaeological Research, The University of Texas at San Antonio.

Chandler, C. K., and K. Hindes

1993 Scottsbluff Points from Atascosa, Frio, and McMullen Counties, South-Central Texas. La Tierra 20(1):31-36.

Chipman, D. E.

1992 Spanish Texas, 1519-1821. University of Texas Press, Austin.

Collins, M. B.

1995 Forty Years of Archaeology in Texas. Bulletin of the Texas Archeological Society 66:361-400.

de la Teja, J. F.

1995 San Antonio de Béxar: A Community of New Spain's Northern Frontier. University of New Mexico Press, Albuquerque.

Dibble, D. S., and D. Lorrain

1968 Bonfire Shelter: A Stratified Bison Kill Site, Val Verde County, Texas. Miscellaneous Papers 1. Texas Memorial Museum, Austin.

Dillehay, T.

1974 Late Quaternary Bison Population Changes on the Southern Plains. Plains Anthropologist 19(64): 180-196.

Ewers, J. C. (editor)

1969 The Indians of Texas in 1830. Publication Series 4745. Smithsonian Institution, Washington, D.C.

Fehrenbach, T. R.

1978 The San Antonio Story. Continental Heritage, Tulsa, Oklahoma.

1983 Lone Star: A History of Texas and the Texans. American Legacy, New York.

Flanagan, S.

1974 Trailing the Longhorns: A Century Later. Madrona, Austin.

Ford, O. L. A., and B. A. Houk

1997 An Archaeological Survey of the SAWS Watson, Howard, Fischer and Quintana Roads Project, Bexar County, Texas. Letter Report, No. 115. Center for Archaeological Research, The University of Texas at San Antonio.

Fox, A. A.

1977a Site Survey Record: The Bly Site (41BX226). Manuscript on file. Center for Archaeological Research, The University of Texas at San Antonio. 
1977b An Archaeological Assessment of the San Antonio 201 Wastewater Treatment Project. Archaeological Survey Report, No. 41. Center for Archaeological Research, The University of Texas at San Antonio.

Fox, A. A., J. McGraw, and F. Valdez, Jr.

1978 Archaeological Survey and Testing of Pipeline and Confluence Site: San Antonio 201 Wastewater Treatment Project. Archaeological Survey Report, No. 66. Center for Archaeological Research, The University of Texas at San Antonio.

Fox, A. A., I. W. Cox, L. Highley, and D. Hafernik

1989 Archaeological and Historical Investigations at the Site of the New Bexar County Justice Center in Downtown San Antonio, Texas. Archaeological Survey Report, No. 184. Center for Archaeological Research, The University of Texas at San Antonio.

Freeman, M. D.

1994 Agriculture in Texas: Ranching and Stock Farming on the Eastern Edwards Plateau, 1845-1941. Komatsu/Rangel, Fort Worth.

Gerstle, A., T. C. Kelley, and C. Assad

1978 The Fort Sam Houston Project: An Archaeological and Historical Assessment. Archaeological Survey Report, No. 40. Center for Archaeological Research, The University of Texas at San Antonio.

Greer, G.

1970 State of Texas Archaeological Survey Record: M. Richter and Sanger Pottery Kilns (41BX129), Elmendorf, Texas. Copy on file. Center for Archaeological Research, The University of Texas at San Antonio.

Habig, M.A.

1968a San Antonio's Mission San José, State and National Historic Site, 1720-1968. Naylor, San Antonio.

1968b The Alamo Chain of Missions, A History of San Antonio's Five Old Missions. Franciscan Herald, Chicago.

Hall, G. D., T. R. Hester, and S. L. Black

1986 The Prehistoric Sites at Choke Canyon Reservoir, Southern Texas: Results of Phase II Archaeological Investigations. Choke Canyon Series, No. 10. Center for Archaeological Research, The University of Texas at San Antonio.

Hard, R. J., A. A. Fox, I. W. Cox, K. J. Gross, B. A. Meissner, G. I. Méndez, C. L. Tennis, and J. E. Zapata 1995 Excavations at Mission San José y San Miguel de Aguayo, San Antonio, Texas. Archaeological Survey Report, No. 218. Center for Archaeological Research, The University of Texas at San Antonio.

Harris, E. S.

1985 An Archaeological Study of the Timmeron Rockshelter (41HY95), Hays County, South Central Texas. Special Publication 4. Southern Texas Archaeological Association, San Antonio.

Hester, T. R.

1968a Paleo-Indian Artifacts Along San Miguel Creek: Frio, Atascosa, and McMullen Counties, Texas. Bulletin of the Texas Archeological Society 39:147-162.

1968b Folsom Points from Southwest Texas. Plains Anthropologist 15(50):237-250. 
1983 Late Paleo-Indian Occupations at Baker Cave, Southwestern Texas. Bulletin of the Texas Archeological Society 53:101-119

1989 Historic Native American Populations. In From the Gulf to the Rio Grande: Human Adaptation in Central, South, and Lower Pecos Texas, edited by T. R. Hester, S. L. Black, D. G. Steele, B. W. Olive, A. A. Fox, K. J. Reinhard, and L. C. Bement, pp. 1-4. Arkansas Archeological Survey Research, Series 33. Arkansas Archeological Survey, Fayetteville.

1995 The Prehistory of South Texas. Bulletin of the Texas Archeological Society 66:427-459.

Howard, C. D.

1974 Paleo-Indian Surface finds in Bexar County. La Tierra 1(4):14-17.

Huebner, J. A.

1991 Late Prehistoric Bison Populations in Central and Southern Texas. Plains Anthropologist 36(137): 343-358.

Inglis, J. M.

1964 A History of Vegetation on the Rio Grande Plain. Bulletin \#45. Texas Parks and Wildlife Department, Austin.

Jackson, J.

1986 Los Mesteños: Spanish Ranching in Texas, 1721-1821. Texas A\&M University Press, College Station.

John, E. A. H.

1975 Storms Brewed in Other Men's Worlds: The Confrontation of Indians, Spanish, and French in the Southwest, 1540-1795. Texas A\&M University Press, College Station.

Johnson, L., Jr.

1967 Toward a Statistical Overview of the Archaic Cultures of Central and Southwestern Texas. Bulletin 12. Texas Memorial Museum, Austin.

1994 The Reconstructed Crow Terminology of the Titkanwatits, or Tonkawas, with Inferred Social Correlates. Plains Anthropologist (39) 150:377-413.

Johnson, L., and T. N. Campbell

1992 Sanan: Traces of a Previously Unknown Aboriginal Language in Colonial Coahuila and Texas. Plains Anthropologist 37(140):185-212.

Jones, W. K.

1969 Notes on the History and Material Culture of the Tonkawa Indians. Smithsonian Contributions to Anthropology 2(5).

Kelley, D.

1971 The Tonkawas. In Indian Tribes of Texas, pp. 151-164. Texian, Waco.

Kelly, T. C.

1993 Preceramic Projectile-Point Typology in Belize. Ancient Mesoamerica 4:205-227. 
Lehmann, V. W.

1969 Forgotten Legions: Sheep in the Rio Grande Plain of Texas. Texas Western, El Paso.

León, A., J. B. Chapa, and F. S. de Zamora

1961 Historia de Luevo León, con Noticias sobre Coahuila, Tamaulipas, Texas y Nueva México. Estudio Preliminar y Notas de Israel Cavzos Garza. Centrio de Estudios Humanistico. Universidad de Nuevo León, Monterrey.

McGraw, A. J., and K. Hindes

1987 Chipped Stone and Adobe: A Cultural Resources Assessment of the Proposed Applewhite Reservoir, Bexar County, Texas. Archaeological Survey Report, No. 163. Center for Archaeological Research, The University of Texas at San Antonio.

Newcomb, W. W., Jr.

1961 The Indians of Texas: From Prehistoric to Modern Times. University of Texas Press, Austin.

1993 The Indians of Texas: From Prehistoric to Modern Times. The University of Texas at Austin.

Nickels, D. L.

1995 An Archaeological Survey of a Proposed Pipeline Route Along Old Corpus Christi and Richter Roads. Letter Report, No. 110. Center for Archaeological Research, The University of Texas at San Antonio.

1998 An Archaeological and Geomorphological Investigation of 103-acre Northrup Park, Boerne, Kendall County, Texas. Archaeological Survey Report, No. 247. Center for Archaeological Research, The University of Texas at San Antonio.

Nickels, D. L., D. W. Pease, and C. B. Bousman

1998 Archaeological Survey of Lackland Air Force Base, Bexar County, Texas. Archaeological Survey Report, No. 248. Center for Archaeological Research, The University of Texas at San Antonio.

Nordt, L. C.

1992 Archaeological Geology of the Fort Hood Military Reservation, Fort Hood, Texas. United States Army Fort Hood Archaeological Resource Management Series, Research Report Number 25. Texas A\&M University, College Station.

1995 Geoarchaeological Investigations of Henson Creek: A Low Order Tributary in Central Texas. Geoarchaeology 10:205-221.

Poyo, G. E., and G. M. Hinojosa (editors)

1991 Tejano Origins in Eighteenth-Century San Antonio. University of Texas Press, Austin.

Shafer, H. J.

1977 Art and Territoriality in the Lower Pecos Region, Texas. Plains Anthropologist 22:13-22.

Sjoberg, A. F.

1953a The Culture of the Tonkawa, A Texas Indian Tribe. Texas Journal of Science 5(3):280-304.

1953b Lipan Apache Culture in Historical Perspective. Southwestern Journal of Anthropology 9(1):76-98.

Skinner, S. A.

1981 Aboriginal Demographic Changes in Central Texas. Plains Anthropologist 26(92):111-118. 
Stahle, D. W., and M. K. Cleaveland

1995 Texas Paleoclimatic Data from Daily to Millennial Time Scales. In The Changing Climate of Texas: Predictability and Implications for the Future. GeoBooks, Texas A\&M University, College Station.

Steele, D. G., and C. Assad Hunter

1986 Analysis of Vertebrate Faunal Remains from 41MC222 and 41MC296, McMullen County, Texas. In The Prehistoric Sites at Choke Canyon Reservoir, Southern Texas: Results of Phase II Archaeological Investigations, edited by G. D. Hall, T. R. Hester, and S. L. Black, pp. 452-502. Choke Canyon Series, No. 10. Center for Archaeological Research, The University of Texas at San Antonio.

Story, D. A.

1985 Adaptive Strategies of Archaic Cultures of the West Gulf Coastal Plain. In Prehistoric Food Production in North America, edited by R. I. Ford, pp. 19-56. Anthropological Papers, No. 75. Museum of Anthropology, The University of Michigan, Ann Arbor.

Swanton, J. R.

1952 The Indian Tribes of North America. Bulletin 145. Bureau of American Ethnology, Washington, D. C.

Taylor, F. B., R. B. Hailey, and D. L. Richmond

1991 Soil Survey of Bexar County, Texas. Soil Conservation Service, U.S. Department of Agriculture, Washington, D.C.

Tennis, C. L., and R. J. Hard

1995 Archaeological Survey of the Upper Leon Creek Terraces, Bexar County, Texas. Archaeological Survey Report, No. 233. Center for Archaeological Research, The University of Texas at San Antonio.

Tennis, C. L., M. Renner, and R. J. Hard (editors)

1996 Archaeological Survey of Laughlin Air Force Base, Val Verde County, Texas. Archaeological Survey Report, No. 239. Center for Archaeological Research, The University of Texas at San Antonio.

Thoms, A. V., B. W. Kuehn, J. E. Olive, P. A. Clabaugh, and R. D. Mandel

1996 Early and Middle Holocene Occupations at the Richard Beene Site: The 1995 Southern Texas Archaeological Association Field School Project. La Tierra 23(4) 8-36.

Turner, S. E., and T. R. Hester

1993 A Field Guide to Stone Artifacts of Texas Indians. Gulf, Houston.

Weir, F.

1976 The Central Texas Archaic. Ph.D. dissertation, Department of Anthropology, Washington State University, Pullman.

Wenke, R. J.

1990 Patterns in Prehistory: Humankind's First Three Million Years. Third edition. Oxford University Press, Oxford, England. 
West, E. H. (translator)

1904 A Brief Compendium of the Events Which Have Occurred in the Province of Texas from its Conquest, or Reduction to the Present Day, Written by Antonio Bonilla in 1772. Quarterly of the Texas State Historical Association VIII(1):1-78.

Woerner, M. C.

1983 Survey and Testing at the Proposed Dos Rios Waste Water Treatment Plant, South Bexar County, Texas: San Antonio 201 Wastewater Treatment Project. Archaeological Survey Report, No. 122. Center for Archaeological Research, The University of Texas at San Antonio. 
